\title{
Na dança e na educação: o círculo como princípio
}

Luciana Esmeralda Ostetto

Universidade Federal da Santa Catarina

\section{Resumo}

Articulando dança e educação, este artigo fala de possibilidades. Tomando os processos educativo-formativos de educadores como foco mobilizador, apresenta e discute conteúdos fertilizados no contexto de uma pesquisa de doutorado, realizada com diferentes grupos de educadoras e desenvolvida por meio de "encontros para dançar em roda”. Na relação constituída entre a experiência com uma específica forma de dança - a dança circular -, e a reflexão sobre a formação de professores, foram identificados alguns núcleos temáticos para a análise. Entre eles, destaca-se a necessidade de contemplar, na jornada de formação, a dimensão estética, cultivando o "ser sensível" presente-escondido no adulto-educador. Considera-se, pois, a implicação de propostas que contribuam para a construção de processos educativos mais inteiros, reaproximando razão e emoção, cognição e afeto. No desenvolvimento da referida pesquisa, o estudo sobre a simbologia do círculo revelou-se essencial e, no presente artigo, configura o eixo central da discussão. São propriedades simbólicas do círculo a perfeição e a ausência de distinção ou divisão. Sua imagem evoca equilíbrio, totalidade, integração de diferenças, interdependência. Roda, círculo, mandala: não é uma bela imagem para a prática educativa? 0 círculo dançante: não seria uma oportunidade para o aprendizado da circularidade na educação? Perpassando tais questões que envolvem a potencialidade do símbolo, propõe-se uma discussão sobre a necessária circularidade dos processos educativos.

\section{Palavras-chave}

Dança e educação - Danças circulares - Formação de professores - Círculo-simbologia. 


\section{In dance and in education: the circle as a principle}

Luciana Esmeralda Ostetto

Universidade Federal da Santa Catarina

\begin{abstract}
Articulating dance and education, this article speaks of possibilities. Considering the educative-formative processes of educators as a driving focus, it presents and discusses issues enriched in the context of a doctorate research conducted with different groups of educators, and developed through the use of "gatherings to dance in circles". In the relationship constructed between the experience with a specific form of dance - the circular dance - and the reflection upon teacher education some thematic units were identified. Among them stands the need to contemplate in the journey of formation the aesthetic dimension by cultivation of the "sensitive being" presenthidden in the adult-educator. We therefore consider the implication of proposals that contribute to the construction of educative processes that are more whole, bringing together again reason and emotion, cognition and affection. In developing this research, studying the symbology of the circle turned out to be essential, and in the present article it constitutes the central point of the discussion. The perfection and the absence of distinction or division are symbolic properties of the circle. Its image evokes equilibrium, totality, integration of differences, interdependence. Wheel, circle, mandala: are these not beautiful images for the educative practice? The dancing circle: would it not be an opportunity for the learning of circularity in education? Running along these issues that involve the potentiality of the symbol, the text proposes a discussion about the necessary circularity of educative processes.
\end{abstract}

\section{Keywords}

Dance and education - Circular dances - Teacher education Circle symbology
Contact:

Luciana Esmeralda Ostetto

Rua Lauro Linhares, 1288 BI. 3/ap. 202

88036-002 - Florianópolis - SC

e-mail: luesmeralda@ced.ufsc.br 
Ao entrar na roda da dança foi que comecei a pensar na carência de símbolos integradores na educação. A simbologia presente nas danças circulares dos povos fez-me pensar na formatação da educação institucional - seja Educação Infantil, Ensino Fundamental, Médio ou Universitário -, em que o quadrado ainda impera como desenho rígido, ângulos retos, linhas estáticas.

Por meio das danças circulares, vi a educação na fôrma, quadrada, e imaginei: se as práticas educativas fossem arredondadas, tudo poderia fluir melhor. Não poderia? Talvez houvesse menos problemas de aprendizagem, distúrbios socioafetivos, doença de professores e crianças e outros males conhecidos na contemporaneidade. 0 quadrado pode ser estrutura que organiza, oferece base, mas também pode ser grade que aprisiona e estanca o fluxo do movimento. Sonho: o círculo, que agrega tudo e todos, girando na educação. Apareceu-me como uma imagem catalisadora, com a força capaz de inspirar a ação educativa nas mais variadas direções. 0 círculo como princípio.

0 que aconteceria se os educadores entrassem na roda, assumindo o girar de mãos dadas, entregando-se à busca e ao mistério do círculo dançante? Articulando dança e educação, este artigo fala de possibilidades. Apresenta e discute conteúdos fertilizados no processo de uma pesquisa (Ostetto, 2006), realizada com grupos de educadoras que aceitaram o convite para dançar em roda: alunas do curso de Pedagogia (no espaço de uma disciplina curricular, eletiva), professoras e outras profissionais da Educação Básica (no espaço de um projeto de formação continuada).

A pesquisa seguiu em busca do que tenho chamado de "ser da poesia" (Ostetto, 2006), por suposto perdido no adulto educador, e foi desenvolvida a partir da organização de "encontros para dançar", envolvendo uma específica proposta de dança - a dança circular. 0 que esteve em foco não foi o ensino da técnica da dança, mas a criação de um espaço diferenciado de partilha, no qual pudesse ser tocada "a pessoa na pessoa" das educadoras, na sua inteireza, que acolhesse pensamento e sentimento, razão e emoção, cognição e afeto.

\section{Sobre as danças circulares}

As danças circulares sagradas trazem em suas raízes a tradição de diferentes povos. Relembram um tempo em que dançar era participação, encontro e reafirmação dos ciclos da vida. Na dança, a comunidade se reunia e celebrava todos os momentos importantes: do plantio à colheita, do nascimento aos funerais (Garaudy, 1980). Como um ritual, os homens dançavam e marcavam seu pertencimento ao grupo, vivendo e partilhando valores e crenças no encontro além da palavra. As danças circulares que hoje praticamos acolhem e honram diferentes povos e tradições. Na roda, compartilhando música, gestos e significados de culturas diversas, tal como no passado, vivificamos ritos e símbolos.

E como se dança? De mãos dadas, o grupo, voltado para um centro comum, descreve formas variadas no espaço. A principal e mais comum é a formação em círculo, que pode abrir-se ou fechar-se, desenhando linhas, espirais, meandros na sua movimentação. As danças de pares são também bastante comuns e lembram diretamente as tradicionais danças de roda festivas. 0 repertório, amplo e variado, inclui, por exemplo, danças da Grécia, Albânia, Romênia, lugoslávia, Bulgária, Hungria, Macedônia, lsrael, Escócia, Irlanda, Rússia, Índia, Brasil, Países Bálticos, Povos Celtas e da América do Sul (sobre o movimento das danças circulares, ver: Wosien, B., 2000; Wosien, M.-G., 2002; 2004; Ramos, 2002).

Para entrar na roda, não é necessário ter conhecimentos nem habilidades específicas sobre dança, basta o desejo. 0 grupo dança para si mesmo, todos entram na roda, pois a coreografia experimentada não tem o objetivo de ser apresentada para uma plateia, que é interna e a dança se revela a cada dançarino em particular.

Na pesquisa, dentre os núcleos temáticos identificados para a análise, considerando a re- 
lação constituída entre a experiência da dança circular e os processos educativo-formativos de educadores, o estudo sobre a simbologia do círculo revelou-se essencial e, no presente artigo, configura o eixo central da discussão.

\section{A hora da roda: da prática ao símbolo}

Sem contar as cantigas de roda, efusivamente festejadas e vivamente presentes na minha infância, a roda me acompanha desde os tempos em que trabalhei na Educação Infantil. Como professora, a prática da roda com as crianças era uma constante no meu fazer pedagógico. Revisitando alguns materiais daquele tempo, encontrei um relatório, elaborado para entregar aos pais no final do ano, em que eu narrava a experiência com o grupo de crianças com idades entre três e quatro anos. Entre as atividades relatadas, lá está a experiência da hora da roda.

No início do ano, quando comecei o trabalho com essa faixa, o primeiro desafio: a adaptação. Eu era professora nova na escola e o grupo, heterogêneo, com crianças que vinham juntas de turmas anteriores, crianças de outras turmas e crianças que estavam chegando novas na escola. Com os conflitos próprios desta fase de adaptação ela se deu, passou e, de um modo geral, houve boa receptividade para comigo e para com a turma toda. Comecei trabalhando pela formação e consolidação do grupo como estrutura de reunião/identificação, ponto essencial para o andamento de qualquer trabalho e de uma proposta pedagógica. Assim, meu objetivo maior nos primeiros meses foi mexer com a identificação e o reconhecimento do grupo - cada criança individualmente e como membro deste; objetivo fundamentado principalmente no fato de existirem crianças "novas" e "velhas" (quanto a já fazerem parte da escola e desta turma). 0 jeito que busquei para a organização e o reconhecimento de que falo acima, foi a criação da hora da roda. Antes de qualquer atividade na manhã, fazíamos uma roda de cadeiras num canto da sala, colocando cadeiras para as crianças presentes e ausentes. Conversávamos sobre "quem é da turma”, "quem faltou”, sempre reforçando os laços que se formavam. Importante canal pra organização do grupo, desenvolvíamos as atividades, o planejamento, a partir desta hora. No início, reuniaos em torno de uma "novidade" que eu trazia - a "surpresa", sempre muito esperada e curtida. No decorrer da convivência, a atração que estava centrada em mim, passou para as crianças que então traziam coisas e mais coisas pra mostrar na roda. A roda passou a ser o momento, por excelência, das grandes trocas e conversações. (Relatório de Grupo. Escola Sarapiquá. Florianópolis, dez. 1985)

Trazer para o presente aquela experiência, nas palavras de meu relatório, é tecer a memória de um símbolo ou de uma prática que tem se tornado central para mim. No entanto, é preciso dizer que em tempos idos eu não pensava em termos de simbologia, de imagem potencialmente marcada no pensamento e que, por isso mesmo, marcava singularmente o cotidiano educativo. A hora da roda era para mim um momento especial da prática pedagógica em que o grupo ganhava visibilidade. Era um ritual de encontro, troca, afirmação de pertencimento e identidade de um grupo - crianças e professora. Encontrando-se no espaço circular, todos "apareciam", podiam dizer e fazer seu discurso ou cena. Exercício de alteridade na aventura de estar com o outro sem controle do conteúdo. Para as crianças, podiam ver e reconhecer umas as outras. Como professora, podia vê-las, reconhecê-las e ver-me, reconhecer-me. 0 que emergia do círculo era um mundo de conhecimento e autoconhecimento.

Mais tarde, trabalhando como coordenadora pedagógica de creches e, depois ainda, como professora do curso de Pedagogia, no contato com inúmeras creches e pré-escolas, fui 
percebendo que a hora da roda ganhava feições e dinâmicas diferenciadas em cada espaço educativo. De modo geral, é uma prática bem conhecida e utilizada na Educação Infantil, recebendo variadas denominações, tais como "rodinha da novidade", "roda de conversa" ou simplesmente "rodinha".

Localizo em Madalena Freire a influência para a introdução da hora da roda na minha prática de professora. Seu livro A paixão de conhecer o mundo, de 1983, assim como outros textos em que socializava suas experiências com diferentes grupos de crianças, transformou-se em fonte e inspiração para meu trabalho. Creio que igualmente para muitos outros professores da minha época, Madalena Freire foi referência, sempre chamando atenção para os rituais de constituição de um grupo. Suas ideias se expandiram, e podemos identificar no livro de Cecília Warschauer, A roda e o registro, publicado em 1993, a continuidade e o aprofundamento de muitos princípios defendidos na década anterior, entre eles a roda como um ritual de grupo. Para essa última autora e educadora, a roda tem como principal característica a abertura para o novo, promovendo o encontro e a integração igualitária de todos os participantes.

De uma forma ou outra, com base nas autoras referidas ou não, a prática da roda difundiu-se. Nas minhas andanças pela Educação Infantil, testemunhei rodas realizadas principalmente na segunda-feira, quando a turma, ao voltar do final de semana, trazia "novidades" para contar. Outras aconteciam diariamente, como forma de iniciar e encaminhar o trabalho planejado pelo professor. Havia também rodas para ouvir histórias ou fazer algum combinado entre o grupo. Práticas diferenciadas, enfim, que em muitos casos tornavam-se um mero fazer e não um ritual de encontro e troca. Por exemplo: se o círculo é a forma que abole as assimetrias, sem divisão, sem hierarquias, ainda permanecia o controle do adulto, impondo uma única direção para o movimento da roda, e pouco havia de interlocução ou escuta atenta do adulto para com as crianças naquele mo- mento que estavam juntos. Poderia até dizer que não era, efetivamente, momento de encontro. Era mais controle, as crianças não ficavam à vontade, pareciam "presas" numa experiência nada prazerosa e pouco significativa. A roda, tão dinâmica e acolhedora na forma e tão significativa na simbologia, transformava-se facilmente em metodologia estéril.

Do que vi, o mais das vezes, não havia um ritual de acolhimento, de escuta. Qualificando as falas ou os gestos das crianças, a roda, desse modo, escorregava para um duro procedimento didático. Lembro da atitude de professores que, diante da voz pouco audível ou da palavra incompreensível de uma criança pequena, ainda estruturando o discurso oral, intercediam: "Ah! Que legal! Então tá bem. Agora o outro coleguinha vai falar...”. E outra criança falava. E a professora "É mesmo? Então tá legal. Agora o outro colega...”. Nesse exemplo, a conversa, como troca, transformava-se em simples formalidade, procedimento didático destituído de significado, uma vez que a intervenção da professora não ajudava a criança, não contribuía para a estruturação do seu discurso. Se não era compreensível sua fala, a professora poderia intervir perguntando, dando outros elementos para a criança se expressar e fazer-se compreender. Poderia efetivamente constituir um diálogo e articular as falas de uma e outra criança. Por que não o fazia? Uma possibilidade: a própria professora não vislumbrava sentido para aquela roda, já que a atividade planejada, a "especificidade" do seu oficio, viria depois. A força do ritual não estava apropriada. Arrisco-me a dizer que, circunscrita aos ditames práticos de certa pedagogia, a professora apenas encaminhava uma técnica e, por isso mesmo, desprovida de significado para si: a roda esvaziava-se, perdia sua simbologia, banalizada num simples jeito de fazer. Como resultado, materializava-se a velha cisão, apartando forma e conteúdo. Apesar do círculo, seguia o cotidiano educativo em linha reta.

Partindo desses antecedentes, as danças circulares sagradas me remeteram a pensar na importância do círculo na educação. Fizeram- 
me ver o círculo na sua essencialidade, como símbolo prenhe de significados para uma prática integradora. Ou seja, mais do que fazer a roda e chamar para o encontro, por si só já uma ação carregada de simbolismo, entra em jogo o exercício de uma atitude e um pensamento circulares. Pensar circularmente significaria não pensar em linha reta, na afirmação da verdade, da única voz, do conhecimento absoluto. Significaria abrir-se ao diálogo, ao acolhimento da dúvida e da diversidade, à construção de múltiplos enredos afirmados no encontro das singularidades de crianças e adultos, de alunos e professores. Não uma técnica, procedimento metodológico, mas um modo de agir, de ser, de acolher. Ademais, como disse o poeta Manoel de Barros (1997), "a expressão reta não sonha".

Dessa forma, em pensamento e atitude, pratica-se no cotidiano a circularidade do conhecimento, negando a unilateralidade. A roda, feito espiral em movimento circular ascendente, une todos, e o seu movimento a cada volta modifica o desenho do cotidiano, da prática pedagógica, integrando papéis e histórias, incorporando as diferenças. Do estranhamento às entranhas do desconhecido na roda do conhecimento, circulando por mundos reais e imaginários, com prazer, sabor e paixão de conhecer.

0 que não era consciente em toda sua potencialidade começa a se tornar evidente na minha jornada acadêmica: no processo da pesquisa de doutorado, fui reconduzida ao símbolo primordial por meio das danças circulares sagradas.

Vivenciar o círculo pela dança é uma experiência transformadora e extremamente linda, tanto quanto o dançarino se deixar envolver. No círculo da dança, não podemos ser apenas espectadores, ficar apenas olhando, de longe. Quem entra na roda é pra dançar! Sabendo ou não os passos, tendo ou não ritmo, com ou sem lateralidade apurada, é girando na roda que tudo pode acontecer, é no movimento que a transformação acontece.

Na roda, ficamos lado a lado, irmanados, ligados pelas mãos e, num crescendo, conforme a entrega de cada um e de todos, ligados pelo coração, o pulso e o impulso criador da unidade na diversidade. 0 foco está no centro da roda que, com o passar da dança, de várias danças, vai impelindo ao encontro com o centro de cada um - seu eixo, seu equilíbrio. Sou parte do todo, mas sou individualidade. Danço a dança coletiva, mas tenho o meu passo, marca do meu corpo, da minha história. Aprendo a entrar na roda sem perder minha singularidade e, mais que isso, reafirmo-a na medida em que percebo o outro. Pratico a alteridade na circularidade: vejo o outro e me vejo, dou espaço ao outro e ocupo meu espaço. Encontro o outro e caminhamos juntos, harmonizando a roda, dançando a vida.

0 círculo. Não é uma bela imagem para a prática educativa? 0 círculo dançante. Não seria uma bela oportunidade para o aprendizado da circularidade?

Se esse símbolo está fortemente presente nas danças sagradas, é porque ele atravessa a história, representado e significado em tempos e espaços distintos, marcando a vida humana na sua relação com a natureza. 0 círculo é uma figura frequente e universalmente empregada e talvez tenha sido mesmo um dos símbolos mais antigos desenhados pela espécie humana (Pennick, 2002). Evocado e provocado por meio da dança, o círculo tem múltiplos significados e, julgando sua importância para a educação, trago a seguir algumas representações que contribuem para a ampliação de sentidos.

\section{Roda, círculo, mandala: abertura para o simbólico}

A forma circular encontra-se no micro e no macrocosmo. Facilmente visível na natureza, dos discos solares e da lua, nas plantas e estruturas geológicas naturais, é perceptível também no corpo humano como, por exemplo, no desenho das células ou no desenho dos olhos. Igualmente é recorrente na cultura, na arte, na produção humana, enfim.

Figura de representação dos ciclos celestes e do ciclo anual configurado no zodíaco, é signo da unidade e da harmonia (Pennick, 
2002). Nas mais diferentes culturas, um dos principais significados do círculo é aquele de representar o universo, a unidade de toda a existência, a totalidade. Seu centro representa a origem de todas as coisas, de todas as possíveis manifestações nele contidas.

Uma imagem comum e bastante conhecida é a do círculo com um ponto ao centro, significando o Sol. Encontramos esse mesmo símbolo no mito de criação do universo segundo a tradição oral Guarani, para a qual o círculo com um ponto no centro significa Ñamundu - o Grande Mistério, o Imanifestado, o Um. Dizem as "palavras formosas" dos Guarani: "Nosso Pai Primeiro/criou-se por si mesmo/na Vazia Noite iniciada” (Jecupé, 2001, p. 22-25).

0 círculo é fonte de toda geometria e o seu maior mistério. Na geometria sagrada, o quadrado representa a matéria, o fenômeno, a estabilidade e a solidez, enquanto o círculo representa o espírito, a essência, a transcendência. Um, o mundo terreno; outro, o mundo celeste (Jaffé, s/d).

0 ideograma alquímico do "uno" é o círculo, que em si mesmo contém o princípio e o fim. No hermetismo, esse símbolo exprime o universo e simultaneamente a "grande obra". Há uma imagem curiosa, relacionada aos símbolos alquímicos, da serpente (ou dragão) que morde sua própria cauda: Oroboro que, ao configurar um círculo com o seu movimento, sugere a ideia de continuidade, vida e morte, eterno retorno. Serve assim à representação mítica do tempo infinito, cíclico e universal. Sobre a significação de oroboro (ou uroboro, uróboro, ouroboros), encontramos no dicionário de símbolos:

A forma circular da imagem deu lugar a uma outra interpretação: a união do mundo ctônico, figurado pela serpente, e a do mundo celeste, figurado pelo círculo. Essa interpretação seria confirmada pelo fato de que o uroboro, em certas representações, seria metade preto, metade branco. Significaria assim a união de dois princípios opostos, a saber, o céu e a terra, o bem e o mal, o dia e a noite, o Yang e o Yin chinês, e todos os valores que esses opostos comportam. (Chevalier; Gheerbrant, 1996, p. 922)

Segundo Jung (1994), "Uróboro, o devorador da própria cauda" talvez seja o mais antigo símbolo configurado da alquimia e aparece em documento datado do Século X ou XI.

Os alquimistas não se cansam de repetir que o opus provém de uma só coisa, devendo retornar ao uno, sendo portanto uma espécie de movimento circular, o do dragão que morde a sua própria cauda. Por essa razão o opus é muitas vezes chamado de circulare $=$ de forma singular ou rota $=$ roda. Mercurius encontra-se no início e no fim da obra. (p. 304-305)

Em diferentes tempos e lugares, o círculo aparece habitando o imaginário e compondo a espiritualidade dos mais distintos povos.

No círculo, como imagem espelhada do universo, as contradições estão suprimidas e toda potência está contida. Início e fim coincidem nele, seu centro é o colo do mundo. (Wosien, 2002, p. 16)

As palavras de Black Elk (apud Wosien, 2002), Homem Santo dos Oglala Sioux, testemunham essa imagem e afirmam a ligação do homem com a natureza, em ciclos que se entrelaçam, desenhando círculos:

Tudo o que a energia do Universo realiza completa-se em um círculo. 0 céu é redondo e eu escutei que a terra é redonda como uma bola e assim também são as estrelas... 0 vento, em sua imensa força, faz redemoinhos. Pássaros constroem ninhos redondos, pois eles têm a mesma religião que nós. 0 sol ascende e declina em círculo. 0 mesmo faz a lua e ambos são redondos. As estações do ano, em suas mudanças, formam um grande círculo e retornam sempre. A vida dos seres 
humanos descreve um círculo, de infância a infância, e assim é com tudo o que é movido por uma energia. Nossas tendas eram redondas como ninhos de pássaros e sempre dispostas em um círculo, o círculo do nosso povo, um ninho de muitos ninhos, nos quais nos criamos e cuidamos de nossa criação segundo a vontade do Grande Espírito. (p. 16)

No Zen-budismo, são encontrados desenhos de círculos concêntricos, simbolizando as etapas do aperfeiçoamento interior, a harmonia progressiva do espírito (Chevalier; Gheerbrant, 1996). 0 círculo representa, naquela tradição, a iluminação, o esclarecimento, a perfeição humana (Jaffé, s/d).

$\mathrm{Na}$ iconografia do budismo tibetano, há a representação da roda cósmica da vida ou Bhavachakra. A imagem da Roda da vida Roda da existência, Roda do Devir e do Vir-aser - é repleta de símbolos distribuídos em três círculos concêntricos, representando cada qual, desde o centro para fora: os três venenos da mente, os seis reinos da existência cíclica e os 12 elos da existência interdependente. A Roda da vida está presa entre os dentes e as garras de Yama, o demônio da morte, símbolo da impermanência (Jung, 2003).

$\mathrm{Na}$ tradição oriental, encontramos uma variedade de círculos coloridos, as mandalas. Palavra que vem do sânscrito, mandala significa literalmente círculo ou centro. 0 seu simbolismo inclui figuras dispostas concentricamente, circunvoluções em torno de um centro, redondas ou quadradas (Jung, 2001). Tradicionalmente, o desenho de uma mandala é composto pelo círculo, símbolo do cosmo, e pelo quadrado, símbolo da terra ou do mundo construído pelo homem (Tucci, 1984). Ricamente ornamentadas, com cores e formas geométricas, as mandalas cumprem um importante papel na tradição oriental, não só entre os budistas, sendo utilizadas com funções religiosas, em rituais e meditações, como expressão da espiritualidade.

Antes de prosseguir falando desse símbolo, um esclarecimento é necessário: segundo o Dicionário Houaiss da Língua Portuguesa, mandala é um substantivo masculino. Todavia, observei que o uso corrente do vocábulo se dá no feminino e entre a literatura consultada raras vezes aparece no masculino. Inclusive nas Obras Completas de C. G. Jung (psicólogo suiço que se dedicou ao estudo da simbologia do círculo) publicadas no Brasil. Apenas um ou outro volume das primeiras traduções trazem a palavra no masculino. Portanto, optei por utilizar "a mandala", no feminino.

Na mandala, está contida a “complexa representação simbólica desse drama da desintegração e da reintegração cósmica”, revivido pelo homem (Tucci, 1984, p. 28). Como instrumento de meditação, torna-se um veículo para concentrar a mente, ampliando seus limites. 0 homem, em contato com o centro da mandala - a morada da divindade, o ponto-instante que contém o infinito e o eterno -, pode estabelecer a conexão com o seu próprio centro, suscitando uma experiência psicológica libertadora. As mandalas de uso ritual, instrumento de contemplação, são chamadas yantra.

A literatura lamaica dá prescrições pormenorizadas sobre como deve ser pintado um círculo desse tipo e como utilizá-lo. Forma e cores são estabelecidas pela tradição, motivo pelo qual as variações se movem dentro de limites relativamente estreitos. (Jung, 2003, p. 353)

As mandalas não se difundiram apenas no Oriente. Igualmente o Ocidente conheceu a utilização dessas formas e, na ldade Média, são encontradas inclusive entre representações da tradição cristã, nas quais "em geral o Cristo é figurado no centro e os quatro evangelistas ou seus símbolos, nos pontos cardeais” (Jung, 2001, p. 38). Pode-se perceber claramente a presença de desenhos de mandalas na arquitetura das igrejas góticas medievais e nas rosáceas das catedrais. No desenho desses vitrais, de cores e beleza impressionantes, há toda uma simbologia inscrita, antigos códigos da geometria sagrada 
nem sempre, ou dificilmente, perceptíveis ao observador comum, mas que no conjunto causam-lhe efeito sobre seus sentidos.

A mandala é mais do que uma simples forma exterior. De acordo com a concepção oriental, "o símbolo mandálico não é apenas expressão, mas atuação" (Jung, 2001, p. 40). Ao contemplar uma mandala ou circunscrever um círculo ritual, o indivíduo está potencialmente tocado pela força do símbolo. É guiado para o centro.

Jung (2001) observou a presença constante dessas formas nos sonhos de seus pacientes psiquiátricos que, ao desenharem as imagens projetadas, experimentavam a organização de elementos desordenados, capturados pela ordem que provinha do centro aglutinador de tais figuras. Curiosamente, alguns pacientes dançavam essas formas circulares.

Algumas de minhas pacientes de sexo feminino não desenhavam, mas dançavam mandalas. Na Índia, isto se chama: mandala nritya, que significa dança mandálica. As figurações da dança têm o mesmo sentido que as do desenho. Os próprios pacientes quase nada podem dizer acerca do sentido simbólico dos mandalas, mas se sentem fascinados por eles. Reconhecem que exprimem algo e que atuam sobre seu estado anímico subjetivo. (p 39)

A circulação, psicologicamente, seria "o ato de mover-se em círculo em torno de si mesmo, de modo que todos os lados da personalidade sejam envolvidos", além de significar a

\section{[...] vivificação de todas as forças lumino-} sas e obscuras da natureza humana, arrastando com elas todos os pares de opostos psicológicos, quaisquer que sejam. (Jung, 2001, p. 41-42)

Ocupado em estudar os mistérios do inconsciente, o psicólogo suiço atribuirá valor essencial ao símbolo, compreendido como um termo, um objeto ou mesmo uma imagem do mundo conhecido que sugere alguma coisa desconhecida ou oculta para nós, alguma coisa que ultrapassa o significado evidente e convencional.

Assim, uma palavra ou uma imagem é simbólica quando implica alguma coisa além do seu significado manifesto e imediato. Esta palavra ou esta imagem tem um aspecto inconsciente mais amplo, que nunca é precisamente definido ou de todo explicado. (Jung, s/d, p. 20)

Do universo de símbolos pelo qual percorreu, a mandala recebeu particular atenção nos seus estudos e pesquisas. Acompanhando o processo de seus pacientes assim como por meio de seu próprio processo, dedicando-se e vivendo a busca do seu mundo interior, de entrega ao inconsciente, Jung viu na mandala a expressão do Self, a "totalidade da psique". A forma circular indicaria sempre o mais importante aspecto da vida - sua extrema e integral totalização que converge para o centro. Escrevendo sobre esse processo na sua autobiografia, testemunha:

Só quando comecei a pintar as mandalas vi que o caminho que seria necessário percorrer e cada passo que deveria dar, tudo convergia para um dado ponto, o centro. Compreendi sempre mais claramente que a mandala exprime o centro e que é expressão de todos os caminhos: é o caminho que conduz ao centro, à individuação. (Jung, 2002, p. 174)

Ao falarmos sobre o estudo do simbolismo da mandala e a emergência dessas formas na produção espontânea de pacientes psiquiátricos, temos que lembrar da Dra. Nise da Silveira (19051999), psiquiatra brasileira. Essa alagoana rompeu com a "psiquiatria dos hospícios", tratando seus pacientes esquizofrênicos, no Rio de Janeiro, com base na expressão artística. Sua longa experiência em hospital psiquiátrico está narrada no livro Imagens do inconsciente, publicado em 1981, por meio do qual vamos tomando contato com a força e a grandiosidade de um trabalho pioneiro. 
Nele podemos testemunhar o encontro de uma mente curiosa e aberta ao "mundo das imagens", aos processos inconscientes e, assim, ao universo simbólico das mandalas:

Imagens circulares ou tendendo ao círculo, algumas irregulares, outras de estrutura bastante complexa e harmoniosa, impunham sua presença na produção espontânea dos frequentadores do atelier do hospital psiquiátrico. Tive grande dificuldade em compreendêlas. A analogia era extraordinariamente próxima entre essas imagens e aquelas descritas sob a denominação de mandala em textos referentes a religiões orientais. [...] Aquelas imagens seriam mesmo mandalas? [...] Ousei então escrever uma carta ao próprio C. G. Jung, enviando-lhe algumas fotografias de mandalas (?) brasileiras. (p. 51)

A carta referida é de novembro de 1954. Em dezembro do mesmo ano, recebe a resposta, com a acolhida do psicólogo suíço, e então pode ter a confirmação:

[...] as imagens do círculo pintadas em Engenho de Dentro eram realmente mandalas. E davam forma a forças do inconsciente que buscavam compensar a dissociação esquizofrênica. (Silveira, 1982, p. 52)

Do trabalho da Dra. Nise, dir-nos-á o analista Roberto Gambini (2003), resultou

[...] a comprovação empírica do caráter autônomo e universal das mandalas como forma eficaz de auto-organização da psique em seus mais dolorosos estados alterados, quando seu centro se perdeu e, com ele, o ego consciente que o expressava. Cada mandala desenhada nesse estado é uma tentativa de resgatar um princípio de reordenamento da mente perdido na loucura. (p. 23)

Inúmeras mandalas produzidas pelos esquizofrênicos com os quais convivia estão hoje nos arquivos do Museu de Imagens do Inconsciente, no Rio de Janeiro, instituição criada por ela em 1952. Em 1957, a Doutora Nise segue para Zurique, para estudar no Instituto C. G. Jung. Naquele mesmo ano, apresenta pinturas e modelagens de vários de seus pacientes na exposição de produção plástica de esquizofrênicos, realizada durante o $2^{\circ}$ Congresso Internacional de Psiquiatria, em Zurique. Pela singularidade, importância e beleza do fato, transcrevo a seguir as palavras da Dra. Nise sobre a visita de Jung à exposição:

A exposição enviada pelo Centro Psiquiátrico do Rio de Janeiro foi aberta por C. G. Jung, na manhã de 2 de setembro. Ele visitou toda a exposição, detendo-se particularmente na sala onde se encontravam as mandalas pintadas por doentes brasileiros, fazendo sobre o assunto comentários e interpretações. Nessa ocasião, uma foto batida por Mavigner fixou Jung, a mão sobre uma mandala, apontandoa com o indicador. Este é um gesto que por assim dizer resume a psicologia junguiana: apontar para o centro, o self, simbolizado na mandala. (Silveira, 1982, p. 52-53)

São propriedades simbólicas do círculo a perfeição e a ausência de distinção ou divisão. Lembremos ainda o conhecido mito: Rei Artur e seus cavaleiros sentavam-se ao redor da távola redonda, comungando princípios, irmanados na jornada da vida. Com o propósito comum, defender o reino e manter a fidelidade ao rei, os cavaleiros reuniam-se ao redor da mesa circular, consagrando a união e a abertura de todos para a aventura e o mistério. 0 rei e seus cavaleiros: na disposição da távola redonda, a configuração de um desenho que marca a unidade. No mito, está claramente presente o símbolo do círculo como forma e espaço em que as assimetrias são abolidas: nele não há hierarquia possível. No salão nobre da távola redonda, todos eram bem-vindos e o rei sentava-se lado a lado com seus cavaleiros.

Sem começo nem fim, o círculo indica atividade, movimento cíclico e tem como carac- 
terística a tendência à expansão, ao ilimitado. Por isso, é associado à mudança e às ideias de incorporar, dar e receber. É essa força que atualizamos e vivificamos nas danças circulares.

\section{Do círculo da dança à circularidade na educação}

Tal qual a dança circular, realizada em roda, a metodologia assumida na pesquisa aqui referenciada poderá igualmente ser denominada "circular": a cada encontro para dançar, iniciávamos a sessão sentados, ao redor de um centro especialmente preparado (dispondo, sobre panos coloridos, flores, velas ou outros objetos simbólicos, conforme a intenção e a temática a ser dançada). Nesse momento inicial - instigado pela indagação: o que ficou do encontro passado? Lembranças, sentimentos, impressões, sensações, relações? -, configurava-se a roda para conversas, trocas, debates, informações. Assim, antes de começarmos a dançar, abríamos o circulo para compartilhar a memória da experiência passada. Nessa hora, fazia anotações do conteúdo revelado no coletivo, constituindo matéria para o detalhamento posterior em meu caderno de campo. Alguns encontros também foram filmados, sobretudo capturando os testemunhos das educadoras, na "roda de conversa", os quais me permitiram rever e ampliar as anotações já realizadas, tecendo meu registro diário. Por fim, as participantes produziram um memorial, descrevendo e analisando a experiência, considerando seus aprendizados e a possível contribuição das danças circulares para sua formação.

Os dados recolhidos no encontro com as educadoras foram organizados e sistematizados, compondo um quadro analítico espiralado, resultado de uma espécie de circumambulatio - aproximar-se circundando, para utilizar a conhecida expressão junguiana (Jung, 2001) -, movimento em torno do que não se mostra totalmente. No processo da pesquisa, a descoberta do que é a pesquisa. 0 objeto chamando o método. Nesse caso, um processo profundamente marcado pela escuta, pela espera e pela utilização de outras linguagens, envolto em busca e mistério - justamente características da experiência estética...

Com esse quadro construído, dando visibilidade às principais questões que emergiram da experiência/pesquisa - entre as quais, a simbologia que envolve o círculo e sua contribuição para a educação; o reconhecimento da "criança interna", constelando o arquétipo do mestre-aprendiz ${ }^{1}$; o silêncio e sua necessária aprendizagem para os educadores -, procedi à discussão dos dados, tomando a psicologia de Carl Gustav Jung e a arte como suportes para a análise.

Conforme já assinalado, entrar na roda para dançar com as educadoras, vivendo o ritual da integração, da totalidade, da unidade na diversidade, possibilitou articular a experiência e alguns dos seus significados, dos quais o círculo emerge como um instigante princípio para se pensar e fazer educação com inteireza e beleza.

Do que se trata aqui não é de compreender esse símbolo, decodificá-lo, falar sobre, explicá-lo aos professores como mais um conceito entre tantos da Pedagogia. Ao contrário, trata-se de incorporá-lo como pensamento e ação, deixando-o penetrar nas práticas educativas, trazendo-lhes o sentido de integração, unidade de opostos, criação. Na apropriação do símbolo, força e direção para a reinvenção do cotidiano, tendo presente o movimento de eterno retorno: passado, presente, futuro; expansão infinita; ilimitados ser e fazer.

Deixá-lo estar como expressão viva que provoca a atuação, busca do centro, reafirmando a dinâmica cíclica de se fazer educação, incorporando as diferenças e acolhendo a dúvida. No símbolo que agrega todos os caminhos e todos os caminhantes, vislumbrar a totalidade. Aprender o círculo, conquistar o centro: possibilidade de equilíbrio do processo ensino-aprendizagem, relação dialógica, na qual todos se educam em comunhão, como queria mestre Paulo Freire.

Como expressão de movimento e mudança, o círculo estaria desalojando a certeza

1. Sobre esse tópico, ver Ostetto (2007). 
e a rigidez da unilateralidade que vimos presente na educação. Tomá-lo como símbolo é dirigir-se para as raias do desconhecido que pode nos conduzir à invenção de outros percursos, senão seguros, mais intensos e inteiros. É abrir espaço para que outras figuras possam surgir na cena pedagógica, para além dos papéis já estabelecidos de professor e aluno. Por que não "buscadores"? Tal como na geometria, todas as formas têm como fonte o círculo, ele mesmo envolvido em mistério. A educação no círculo poderá gerar uma multiplicidade de formas de conhecer e de conhecimento (talvez esteja aí a possibilidade de incorporar a arte como conhecimento essencial, tirando-a da marginalidade a que esteve reduzida até agora, esquecida nos porões das escolas e da vida).

Mais uma vez são as palavras de Jung (2002) que impulsionam o estabelecimento de relações e nexos entre danças circulares e formação de educadores. Quando ele diz: Formação-Transformação, eis a atividade eterna do eterno sentido. A mandala exprime o si-mesmo, a totalidade da personalidade que, se tudo está bem, é harmoniosa, mas que não permite o autoengano (p. 173; grifos do original), estende uma ponte oferecendo passagem para pensar aquelas relações. Faz-me pensar que poderia atribuir à roda da dança, como mandala em movimento, uma específica "atividade de formação - transformação”, daqueles que dela participam e a ela se entregam. Ao entrar na dança circular, a pessoa é requisitada por inteiro e, se tudo está bem, logo se harmoniza no movimento do grupo. Do contrário, há desarmonia, com sentido de desintegração, fragmentação, distancia-se do centro, do equilíbrio grupal. Está na roda, mas segue em linha reta. Está com os outros, mas segue só. Vai em frente, mas se prende ao que ficou atrás. A roda da dança também não permite o autoengano: revela a pessoa por inteiro no decorrer dos passos, passo a passo, volta após volta. Se há busca: há entrega, há encontro. Se há resistência: há entrave, há desencontro. No girar da roda, gradualmente, é que o dançarino poderá ou não estabelecer conexão com a música, os passos, os outros dançarinos, harmonizando-se até conquistar o seu eixo, o seu centro. Nesse instante, pode-se dizer que o dançarino constelou o símbolo em si, mudou, transformou sua visão ou o alcance do olhar, acompanhado do sentimento e do pensamento redimensionados. Integrou-os. Integrou-se.

E então chego à consideração que anunciei: se o dançarino-professor experimenta o círculo, entregando-se ao movimento "mandálico" da dança circular, poderá incorporá-lo no cotidiano educativo com as crianças - em pensamento e atos, não só em palavras. Viver a “circulação", como aproximação de pares de opostos culturalmente dissociados, poderá provocar a abertura para o novo, para a recriação do cotidiano educativo. É disso, pois, que pode tratar a proposta das danças circulares no âmbito da formação de professores: constelar o símbolo a partir da experiência.

Do processo compartilhado com as educadoras na pesquisa, apresento a seguir um recorte da análise de situações e dados observados, ampliando a significação e confirmando possibilidades de aprendizagens circulares na dança e na educação.

\section{Para dançar em círculo foi preciso sair do lugar...}

Todos os grupos, ao chegarem, no primeiro dia, sentaram-se acompanhando o desenho da sala, colados às paredes (que não eram redondas) ou nas cadeiras dispostas por toda a sala, em filas. Pareceu natural seguir aquela disposição, na formatação dada, uma vez que faz parte do hábito assumir o quadrado que impera inclusive no espaço arquitetônico. Nele, o direcionamento é evidente: imobilidade, isolamento, as pessoas uma lá e outra cá, dificuldade de diálogo. Quando chamadas para o círculo, um movimento, quase agitação, ficou evidente: nem todas gostam nem todas estão disponíveis para redefinir a forma e se incorporar ao círculo. Vi nessas reações a indicação de 
certa compreensão, mesmo que primariamente no sentimento das participantes, do que poderia provocar a roda: eu vou aparecer, não posso me esconder, estou irremediavelmente incluída na história. E então? Sem entrar na roda, não é possível viver a circularidade.

No caso da experiência que deu base à pesquisa, grande parte das educadoras saiu do seu lugar - já estabelecido, conhecido, aterrado, estável. Muitas entraram no fluxo do movimento da roda e acenaram positivamente para a ampliação do entendimento do princípio da circularidade implícito. Atitude visível, por exemplo, no envolvimento crescente com as danças, que fluiam notoriamente mais leves com o passar dos encontros.

Se a dança circular é um convite, é possível afirmar que no contexto da pesquisa todas as participantes aceitaram-no, pois vieram para a roda e nela permaneceram até a finalização, estendendo as mãos, entrelaçando-se no girar das danças dos povos. Dançar, todas dançaram. 0 que não significa dizer que não houve resistência nem tampouco significa afirmar que o aprendizado e entrega foram homogêneos! Apropriar-se dos significados decorrentes, a dificuldade para o silêncio, o riso incontido, a atitude dispersiva, por exemplo, foram consideradas formas de resistência ${ }^{2}$. Na dinâmica das "rodas de conversa", a posteriori, tais aspectos foram retomados e discutidos. Minha função, como pesquisadora-focalizadora, era também sinalizar esses pontos, abrindo canal para a reflexão, reconduzindo a roda com a possibilidade de ampliação de significados. Nesse campo, os aprendizados são sutis, requerem outra qualidade de tempo...

\section{Desenhar mandalas: abertura para o simbólico}

Além de dançar, também propus aos grupos a produção de desenhos de mandalas, outra possibilidade de trazer o símbolo à consciência. A maioria não sabia o que era uma mandala, não tinha informações sobre seu sig- nificado e, mesmo assim, depois de algumas palavras minhas a respeito da forma e da simbologia, houve a entrega. A disposição dos grupos, seu envolvimento para desenhar as formas circulares desconhecidas, surpreendeuse. 0 prazer em produzirem os desenhos, assim como a satisfação pelo resultado de mandalas coloridas, era visível. Ao apresentarem seus desenhos para o grupo e colocá-los no centro da roda, várias educadoras expressavam sua "incredulidade" diante da produção: "nossa, eu fiz, nem acredito!”, exclamavam, exprimindo contentamento com a criação, resultado de um encontro consigo e com a beleza, eu diria também. Trago a seguir algumas vozes, recolhidas dos registros das educadoras, que dizem do seu encontro com a mandala.

Hoje o que mais me deixou tensa e ao mesmo tempo me surpreendeu foi desenhar e colorir uma mandala. Tensão pelo fato do novo, de nunca ter feito e surpresa, pois ao terminar achei que consegui transmitir o que dançamos, minhas sensações e sentimentos nas formas e cores. (Thais)

Hoje filmamos uma dança para a nossa formatura. Qual a escolhida? "Mandala da lrlanda" (lrish mandala)! Ao final da noite, fizemos mandalas e apresentamos os desenhos para a classe. Quando vi o resultado de todos, foi lindo: ficaram muito interessantes e coloridos! Parece que todos juntos formamos uma "mandala humana". (Lia)

Enquanto desenhava, não tinha como apagar os erros. Precisava pensar em estratégias para retomar o desenho e reorganizar a harmonia da mandala. Pensei na vida: não temos como apagar certas situações que desagradam; precisamos, a partir delas, reconduzir nossa caminhada, incorporando-as. (Adriana)

2. Na tese (Ostetto, 2006), discuto esses dados em tópico específico, 0 que não seria possível desenvolver no limite do presente trabalho, sendo matéria para outro artigo. 
Conheci as mandalas muito antes das danças circulares. Pintava-as como uma forma de recolhimento, pausa para deixar que emoções e pensamentos fluíssem através das cores. Era um retorno a um tempo em que eu, criança, me aquietava, e deixava que cores, formas, sons, cheiros, sentimentos, lembranças se aproximassem de mim. As danças circulares despertaram algo parecido e acrescentaram outras mãos, olhares, sorrisos, movimentos, e eu não tive dúvidas, faria meu registro através de mandalas. (Desirée)

0 grupo que, além de desenhar, bordou uma mandala experimentou ainda mais o desafio, pois se desenhar era novidade, bordá-la era uma novidade ainda maior. 0 essencial de todo o processo foi a disposição evidenciada para a criação e o que surgiu foi muito bonito. Nessa simples atividade de desenhar formas circulares e depois transformá-las em bordados, esteve implicada a totalidade de cada participante e um reencontro com o "feito à mão". Tal como assinalado pela escritora lygia Bojunga (2001) no seu livro Feito à mão, vi no trabalho das educadoras um processo de redescoberta de muitos "eus", presentes e escondidos em cada uma. A alegria ao mostrarem sua produção e a satisfação com que afirmavam "eu fiz!" conduziram-me a pensar e a afirmar a necessidade de abrirmos canais para a redescoberta desses "muitos eus" do adulto-educador, entre os quais está o "eu-artesão", que acaba ficando esquecido, por debaixo das muitas camadas de vida. Testemunhando seu processo de reencontro com o "feito à mão", é a escritora que nos diz:

[...] o meu eu-artesã, salvo uma aparição ou outra, das quais eu nem tomei muita consciência, ficou lá por baixo das várias camadas de vida que foram me acontecendo. (p. 87)

Há um “desprezo não disfarçado pelo feito à mão", numa sociedade onde a tecnologia impera (Bojunga, 2001). E assim o imenso potencial criativo do ser humano é interrompido, negado, frustrado, na mesma medida em que o ser é empobrecido na sua capacidade de realizar, de realizar-se. No caso dos educadores, a necessidade de provocar esses "muitos eus" é essencial. Entrar na roda, dançar no círculo, desenhar círculos pode ser um ensaio de provocação.

\section{Uma mandala em mosaico: paciência em pedacinhos de tempo e espaço cultivados}

Uma educadora construiu, para a finalização de nossos encontros de dança, uma mandala em mosaico. Ao apresentá-la ao grupo, contou da significação: cada pedacinho do mosaico era parte da paciência desenvolvida nas danças, para ficar na roda, no silêncio, no ritmo lento. Disse que foi uma experiência diferente e precisou realmente de paciência, pois é agitada, e a dança, principalmente as mais lentas, não era a coisa que mais gostava. Nas suas palavras, confessou que esteve desenvolvendo a tolerância e contato consigo mesma.

$\mathrm{Na}$ sua mandala-mosaico, o sentido ganhava materialidade. Esse testemunho oferece uma visão do que pode fazer a dança - não é magia, não é de uma hora para outra que acontece a mudança, é processo. Outro aspecto que se pode ressaltar, no caso dessa educadora, foi que ela não saiu correndo, mesmo "sem gostar de dançar”. Experimentou a roda, colocou-se no movimento a dançar e, ao final, desenvolveu essa qualidade da paciência que, simbolicamente, pode ser tomada como a harmonia do círculo, constituído por muitos e inúmeros pedacinhos de tempo, espaço, pensamento, sentimento, encontros. Matéria da vida.

\section{Do centro da roda de dança ao centro com as crianças}

Uma aluna, que já atuava como professora, chegou para me contar, no intervalo de um encontro, sobre suas aulas e suas crianças. Jamais esqueci a forma como ela me contou a 
experiência, o brilho no olhar, o prazer e a alegria de me passar seu testemunho. 0 que ela disse? Falou que, depois que começara a dançar ao redor de um centro, levou a ideia para suas aulas. Ela já fazia a roda para conversar ou ler histórias para as crianças, mas desde então, experimentou organizar também na sua sala um centro, tal qual fazíamos para dançar: levou panos coloridos, alguns objetos e arrumou bonito para as crianças. A reação das crianças não poderia ser melhor: gostaram da novidade e sentiram algo especial naquela arrumação. A professora contou que a participação na roda foi mais intensa, notou uma crescente aproximação física e demonstração de afetos entre as crianças. Lições do círculo!

Nesse caso, digo que, além da forma, da marcação carinhosa de um espaço especial para a conversa, esteve em jogo também uma estética: do aconchego, da beleza, do acolhimento, constituindo um ritual. Há uma força incrível nas ações ritualizadas que, por isso mesmo, potencializam o símbolo. Afinal, "Todos os pontos da circunferência reencontram-se no centro do círculo, que é seu princípio e seu fim" (Chevalier; Gheerbrant 1996, p. 251). Quando nos reunimos em roda e estabelecemos um centro comum, seja na dança ou na prática educativa, é em torno dele que giramos e nos harmonizamos. Estabelecer uma conexão com o centro, em grupo, é buscar simbolicamente a luz, a fonte, a criação. 0 eixo que une todos e provoca o movimento.

\section{A circularidade não é algo que se decrete}

Como coordenadora da roda (dizemos focalizadora), dirigia-me para o círculo com um roteiro: a dança, seus passos, sua música. Convidava todos para a viagem. Todavia, tinha sempre presente: quem aceitaria o convite, como viajaria, até onde chegaria? É o mesmo processo ensino-aprendizagem que identificamos no contexto educacional: o professor faz o convite, tem um roteiro, mas a viagem do conhecimento ganhará sabor e alcance distintos para cada viajante. Pretenderia o professor que todos compartilhassem o mesmo gosto, o mesmo prazer e satisfação na aventura de conhecer? Sim, mas a homogeneidade não é possível. Os processos são diferenciados, porque diferenciados são os indivíduos. Além do que pode haver resistência, recusa e outras dificuldades no percurso. 0 que fazer? Romper o círculo ou entregar-se ao aprendizado, na roda, com todos, lado a lado. Seja no papel de focalizadora na roda da dança, seja como professora na prática pedagógica institucional, creio que tanto mais estaremos abertos ao processo de aprendizagem quanto mais incorporarmos a dinâmica do círculo. Circular é também pendular: aprender a cair, reconhecer os erros, recomeçar, equilibrar-se. Tanto na dança quanto na sala de aula, a partir do reconhecimento dos limites e na direção da expansão, podemos vivificar o símbolo, percebendo o processo de aprender como fonte inesgotável de começo e recomeço, morte e renascimento, eterna recriação, tal qual a imagem mítica oroboro.

Identifico, nas situações apresentadas, indícios de que o símbolo foi trazido à consciência daquelas que se deixaram tocar no encontro com o mistério. No entanto, a mudança não é algo que se decrete, assim como a circularidade não é algo que se recite. Se é conceito, é antes de tudo ação, atitude-pensamento que passa pelo coração, sopro da vida (Hillman, 1993), capaz de despertar outras funções da consciência, além da racionalidade. Como nos diz Gláucia Rodrigues (2002):

As pessoas que dançam vão percebendo, com o passar do tempo, as mudanças que ocorrem em si mesmas. Não é só o corpo físico que se torna mais leve, ágil, alegre, mas também a alma pois, assim como nos tornamos mais flexíveis em nossas articulações, também o fazemos em nossas reflexões. A forma retilínea de pensar vai se tornando mais "arredondada", "espiralada": o sentido de "um" e do "todo" está sempre 
presente. Ao dançar vamos deixando para trás julgamentos, críticas, ideias, preconceitos, ficamos mais harmonizados, identificados e de acordo com o compasso do coração, do Amor. Vale lembrar que "acorde" vem da raiz latina cor, que significa coração. (p. 51)

A percepção do aprendizado da circularidade como processo pode ser testemunhado no depoimento de uma aluna afirmando que a roda não atinge a todos. É necessário tempo para a escolha, para deixar-se reconhecer pertencente ao círculo dançante:

No círculo somos estimulados a participar de forma integral em uma ação que vem do coração; somos colocados em uma disposição especial que considera todos os presentes... e eu não senti este movimento acontecendo com todos na maioria dos encontros. [...] Encontros e desencontros, conforto e desconforto, solidariedade e indiferença, fomos dançando, aprendendo a ser tolerantes [...]. Mas nem tudo estava perdido e sempre houve uma chance de a roda fluir: a segunda parte de aula, depois do intervalo, quando o grupo diminuía. Aí acontecia a integração, reconhecia-se a igualdade de todos e a presença única de cada dançarino, o corpo embalado pela música e o olhar brilhante. (Dulciley)

$\mathrm{Na}$ experiência da pesquisa com as danças circulares, certamente muitas educadoras foram tocadas. Quantas? Em que medida? Difícil saber. A roda da dança apenas sinalizou caminhos. Fazer a travessia e depois continuar - seja a dança, seja a prática circular com as crianças, na escola e na vida -, será processo de cada uma.

\section{Referências bibliográficas}

BARROS, M. de. Livro sobre nada. 4. ed. Rio de Janeiro: Record, 1997.

BOJUNGA, L. Feito à mão. 2. ed. Rio de Janeiro: Agir, 2001.

CHEVALIER, J. ; GHEERBRANT, A. Dicionário de símbolos. 10. ed. Rio de Janeiro: José Olympio, 1996.

FREIRE, M. A paixão de conhecer o mundo. Rio de Janeiro: Paz e Terra, 1983.

GAMBINI, R. A íris do terceiro olho. In: SARTORI, L. A água e seus exercícios: catálogo da exposição. São Paulo, 2003, p. 21-29.

GARAUDY, R. Dançar a vida. Rio de Janeiro: Nova Fronteira, 1980.

HILLMAN, J. Cidade e alma. São Paulo: Studio Nobel, 1993.

JAFFÉ, A. 0 simbolismo nas artes plásticas. In: JUNG, C.G. 0 homem e seus símbolos. 10. ed. Rio de Janeiro: Nova Fronteira, s/d. p. 230-271.

JECUPÉ, K. W. Tupã Tenondé: a criação do universo, da terra e do homem segundo a tradição oral Guarani. São Paulo: Peirópolis, 2001.

JUNG, C.G. Psicologia e alquimia. 2. ed. Petrópolis: Vozes, 1994.

0 homem e seus símbolos. 10. ed. Rio de Janeiro: Nova Fronteira, s/d.

Memórias, sonhos, reflexões (Reunidas e editadas por Aniela Jaffé). Rio de Janeiro: Nova Fronteira, 2002.

Comentário Europeu de C. G. Jung. In: JUNG, C. G.; WILHELM, R. 0 segredo da flor de ouro. 11. ed. Petrópolis: Vozes, 2001. p. 21-80. 
Os arquétipos e o inconsciente coletivo. 3. ed. Petrópolis: Vozes, 2003.

OSTETTO, L. E. Educadores na roda da dança: formação-transformação. 2006. Tese (Doutorado)- Faculdade de Educação da Universidade Estadual de Campinas, Campinas, 2006.

. Na jornada de formação: tocar o arquétipo do mestre-aprendiz. Pro-Posições. Campinas, v. 18, n. 3 (54), p. 195-210, set./dez. 2007.

PENNICK, N. Geometria sagrada: simbolismo e intenção nas estruturas religiosas. 6. ed. São Paulo: Pensamento, 2002.

RAMOS, R. (Org.). Danças circulares sagradas: uma proposta de educação e de cura. 2. ed. São Paulo: TRIOM, 2002.

RODRIGUES, G. Mudanças. In: RAMOS, R. (Org.). Danças circulares sagradas: uma proposta de educação e de cura. 2. ed. São Paulo: TRIOM, 2002. p. 43-53.

SILVEIRA, N. da. Imagens do inconsciente. 2. ed. Rio de Janeiro: Alhambra, 1982.

TUCCI, G. Teoria e prática da mandala. São Paulo: Pensamento, 1984.

WARSCHAUER, C. A roda e o registro. Rio de Janeiro: Paz e Terra, 1993.

WOSIEN, B. Dança: um caminho para a totalidade. São Paulo: TRIOM, 2000.

WOSIEN, M.-G. Danças sagradas: deuses, mitos e ciclos. São Paulo: TRIOM, 2002.

Dança: símbolos em movimento. São Paulo: Ed. Anhembi-Morumbi, 2004.

Recebido em 08.06 .08

Aprovado em 12.02.09

Luciana Esmeralda Ostetto, doutora em Educação (Unicamp), professora do Centro de Educação da Universidade Federal de Santa Catarina; trabalha com os seguintes temas: educação infantil e prática pedagógica, arte e infância, arte e formação de professores; e coordena o projeto "Danças circulares na educação: formação de professores na roda". 